\title{
Implementing state support for small agricultural businesses in the Russian Federation
}

\author{
Gulnara Nigmatullina ${ }^{1, *}$, Elina Kipchakbaeva ${ }^{2}$, Alisa Ableeva ${ }^{l}$, Aigul Askarova ${ }^{l}$, and \\ Guzel Salimova ${ }^{l}$ \\ ${ }^{1}$ Bashkir State Agrarian University, Ufa, Russian Federation \\ ${ }^{2}$ Ministry of Agriculture of the Republic of Bashkortostan, Ufa, Russian Federation
}

\begin{abstract}
The paper describes the current level of small farm business development in the Russian Federation and the Republic of Bashkortostan. The existing regulatory framework provides a wide range of measures to implement state support for the agricultural sector. The state aid mechanism and influence on the efficiency of agricultural production in microenterprises, budget efficiency, the need and prospects for directing budget funds for the development of small agricultural businesses are considered. The Bashkortostan Republic's agricultural industry and perspective small farm business development in the region are assessed. The efficiency of allocating budget funds of the region's consolidated budget is calculated.
\end{abstract}

\section{Introduction}

Small businesses are individuals engaged in business without a legal entity, as well as small commercial companies.

The criteria for classifying an enterprise as a small business vary from country to country. In Russia, there are limits on the number of employees and the turnover [1]. In Germany, as in all European Union countries, economic entities are classified as small and medium enterprises by EU Recommendation 2003/361/EG of 2003. These recommendations specify companies with 10 to 49 employees and an average annual turnover (balance sheet amount) of up to 10 million euros as small businesses [9].

Three criteria are used in the United States to type companies as small: the business sphere, the staff number, and the regulatory requirements. The number of employees in the smallest entities (microenterprises) does not exceed 25 people, including the owner. Small businesses are companies with 25 to 99 employees. An annual turnover of a small agricultural business should not exceed 0,75 million dollars, but there are exceptions for agriculture sub-sectors. Thus, livestock farms that keep animals on feeding lots with a 7.5 million dollar turnover and chicken egg producers with a turnover of 15 million dollars are small businesses [4].

\footnotetext{
*Corresponding author: nigmatullina419@yandex.ru
} 
The considerable contribution is made by small businesses producing original and specific products on limited farmlands in sparsely-populated localities. As a rule, the head in one person is responsible for the farm's production and financial activities [9].

As many authors claim, small business is a specific business structure. Starting a small business does not require large start-up capital, providing additional competition and jobs [3].

Small business development started in Russia in the early 1990s under overcoming the economy's archaic structure with dominated large enterprises and foreign product importers, strong opposition to bureaucratic structures, and an imperfect regulatory framework [11].

Small business faces such challenges as difficulties in expanding production (establishing sales channels, lack of working capital), time pressure for the head of an enterprise to get informed with new regulations and provisions for production activities (new standards, requirements, etc.) [36]. These factors confirm the relevance of this study and reflect the specifics of Russia.

A review of the scientific literature shows that similar problems have existed in different countries for a long time. Scientists are looking for ways to solve them and develop small agricultural businesses.

First, market economy development involves cooperation as the main factor determining the competitiveness of economic entities.

Much attention in Russia is paid to agricultural cooperation in regions and across the country, training personnel to work under cooperation and integration [13].

Dramatic changes in the agricultural sector and the economy require new tools and strategies for small business development. The scientists discuss challenges in the agricultural business, risk anticipations, farming development tools, the interrelationship of agricultural and economic sciences, making the right management decisions based on multiple criteria [10].

It is noted that further expansion of agriculture, biodiversity, and sustainable development should rely on a strong regulatory framework at different administrative levels, economic and non-economic incentive schemes for small farmers [11].

Information and communication technologies can significantly improve small-scale farming, including access to simple and complex knowledge and the development of business relationships. They are essential in terms of access to state support measures for small businesses in rural areas [12].

Thus, the Russian legislation provides for a set of regulations that administer the activities of small businesses and contribute to their development. Russian Federal law No. 209-FZ of July 24, 2007 (as amended on June 08, 2020) "On the development of small and medium-sized businesses in the Russian Federation" stipulates the main goals and principles of state policy in the field of small and medium-sized businesses [5].

The state policy makes a clear delimitation between federal government bodies, state authorities of the subjects of the Russian Federation, and local governments to deal with the support to small and medium businesses. It places their responsibilities and ensures equal access to receive support by the terms of its provision.

State support for all agricultural producers is provided under the current state program "Development of agriculture and regulation of markets for agricultural products, raw materials, and food," approved by Decree of the Russian Government No. 717 of July 14, 2012 (with subsequent amendments) [6]. 


\section{Materials and Methods}

To achieve this result, it is necessary to take into account the growth of financial support for state programs at the federal level. Thus, the share of the i-th subject of the Russian Federation in the indicators of farm development (a10i) is calculated using the formula [6]:

where:

$$
a_{10 i}=\frac{\left(0,2 \times \mathrm{D}_{\text {gross } i}+0,8 \times D_{\text {spacei }}\right) \times Y_{i}}{\sum_{i=1}^{n 10}\left(0,2 \times \mathrm{D}_{\text {gross } i}+0,8 \times D_{\text {spacei }}\right) \times Y_{i}}
$$

$\mathrm{n} 10$ - the number of subjects of the Russian Federation where the development of small businesses is a priority for the corresponding financial year.

Priority is identified by statistical sampling based on subsidy rates calculated for one calendar year with a ceiling of 11 thousand units for peasant farm enterprises and agricultural consumer cooperative;

$\mathrm{Yi}$ - the maximum level of co-financing of the expenditure obligation of the i-th subject of the Russian Federation from the Federal budget for the next financial year, \% [7];

D grossi - the share of the average value of the gross crop and livestock production produced by private farms, including sole proprietors, in the i-th subject of the Russian Federation for three years preceding the current financial year, in the average value of the gross crop and livestock production produced by farms, including sole proprietors, for three years preceding the current financial year [6].

The given paper relies on this method to make calculations for the Republic of Bashkortostan

\section{Results and Discussion}

The estimated amount of support for the Republic of Bashkortostan to finance small business development activities will be at least 837.6 million rubles in 2020 .

There is the Russian national program "Small and medium-sized businesses and support for individual entrepreneurship" to support small and medium-sized businesses in agriculture (approved by the Presidium of the Presidential Council for strategic development and national projects, Protocol No. 16 of December 24, 2018). Implementing the national project in 2019-2024 is ensured by allocated 37.4 billion rubles of the Federal budget funds with 126 thousand people involved in small agricultural businesses, including:

- number of newly created farmers - 8,187 units

- the number of additional jobs - 16,375 units.

- increased agricultural consumer cooperative membership - 102,128 units.

Table 1. Results of agricultural cooperation

\begin{tabular}{|c|c|c|}
\hline \multicolumn{2}{|c|}{$\begin{array}{l}\text { Rating of the Russian subjects by the number of } \\
\text { established agricultural cooperatives for 2018-2019, \% }\end{array}$} & $\begin{array}{l}\text { Growth in gross output of } \\
\text { peasant farm enterprises and } \\
\text { sole proprietorship farms, } \%\end{array}$ \\
\hline Republic of Bashkortostan & 16 & 118.9 \\
\hline Republic of Tatarstan & 7 & 120.8 \\
\hline Krasnodar region & 6 & 116.1 \\
\hline
\end{tabular}

The sub-program "Support of small-scale farms and development of rural cooperation" is realized under the state program "Development of agriculture and regulation of markets of agricultural products, raw materials, and food in the Republic of Bashkortostan," approved by the Government Decree of the Republic of Bashkortostan No. 458 of December 17, 2012 (as amended). Thanks to the implemented subprogram, the share of 
agricultural production farms increased from $4 \%$ in 2010 to $12.9 \%$ (or more than 21.5 billion rubles) in 2019. 856 farms and 19 agricultural consumer cooperatives participated in grant programs. More than two thousand new farms have been created. In total, about 3.2 billion rubles of budget funds were allocated for all programs for the period 2012-2019, and state support was provided to 1,224 small businesses [5].

In 2019, the share of small businesses in the production of main crops: grain $-32.5 \%$ (in $2018-32.8 \%)$, sunflower $-35.3 \%(30.1 \%)$, sugar beet (factory) - $22.2 \%(21.9 \%)$, due to better material and technical base, a higher share of cultivated lands $(+20$ thousand hectares), and a corresponding increase in yields. According to the results of spring sowing in 2020 , the area under crops increased by $105.6 \%$. There is also a rise in the production of livestock products. In 2019, livestock and poultry production for slaughter in live weight increased by $3.9 \%$, milk by $8.4 \%$, compared to 2018 .

Last year, state support for small-scale agricultural producers amounted to more than 1 billion 160 million rubles, of which: 579.5 million rubles from the Federal budget and 342.9 million rubles from the budget of the Republic of Bashkortostan, 240 million rubles own funds. 620 new jobs were created for 108 new agricultural consumer cooperatives and 129 new peasant farm enterprises.

Table 2. Efficiency of loans and subsidies for agriculture in the Republic of Bashkortostan in 2009 and 2019

\begin{tabular}{|c|c|c|c|c|c|c|}
\hline \multirow{2}{*}{ Indicators } & \multicolumn{2}{|c|}{2009} & \multicolumn{2}{|c|}{2019} & \multicolumn{2}{|c|}{$\begin{array}{c}\text { Relation of } 2019 \text { to } \\
2009\end{array}$} \\
\hline & $\begin{array}{l}\text { Agricultural } \\
\text { enterprise }\end{array}$ & $\begin{array}{l}\text { Private } \\
\text { farm }\end{array}$ & $\begin{array}{l}\text { Agricultural } \\
\text { enterprise }\end{array}$ & $\begin{array}{l}\text { Private } \\
\text { farm }\end{array}$ & $\begin{array}{l}\text { Agricultural } \\
\text { enterprise }\end{array}$ & $\begin{array}{l}\text { Private } \\
\text { farm }\end{array}$ \\
\hline \multicolumn{7}{|c|}{ Loans granted } \\
\hline $\begin{array}{l}\text { per } 1 \text { ha of } \\
\text { farmland, ruble }\end{array}$ & 637,9 & 480,7 & 1208,4 & 929,9 & 189,4 & 193,5 \\
\hline $\begin{array}{l}\text { per 1 ruble of } \\
\text { gross output, } \\
\text { ruble }\end{array}$ & 0,15 & 0,05 & 0,11 & 0,09 & 74,1 & 178,4 \\
\hline $\begin{array}{l}\text { per one farm, } \\
\text { thousand dollars }\end{array}$ & 3071,4 & 56,3 & 8396,2 & 370,1 & 273,4 & 657,4 \\
\hline \multicolumn{7}{|c|}{ Subsidies received } \\
\hline $\begin{array}{c}\text { per } 1 \text { ha of } \\
\text { farmland, ruble }\end{array}$ & 1095,9 & 87,03 & 784,3 & 1279,2 & 71,6 & 1469,8 \\
\hline $\begin{array}{l}\text { per } 1 \text { ruble of } \\
\text { gross output, } \\
\text { ruble }\end{array}$ & 0,26 & 0,83 & 0,07 & 0,12 & 28,0 & 14,8 \\
\hline $\begin{array}{l}\text { per one farm, } \\
\text { thousand ruble }\end{array}$ & 5277,0 & 10,2 & 5449,7 & 509,1 & 103,3 & 4991,0 \\
\hline \multicolumn{7}{|c|}{ Produced products } \\
\hline $\begin{array}{c}\text { per } 1 \text { ha of } \\
\text { farmland, ruble }\end{array}$ & 6366,8 & 10443,0 & 10699,5 & 10422,5 & 255,7 & 151,3 \\
\hline $\begin{array}{l}\text { per } 1 \text { ruble of } \\
\text { loans granted, } \\
\text { ruble }\end{array}$ & 5,3 & 21,7 & 8,85 & 11,21 & 168,3 & 51,6 \\
\hline $\begin{array}{l}\text { per } 1 \text { ruble of } \\
\text { subsidies } \\
\text { received, ruble }\end{array}$ & 6,9 & 120,0 & 13,64 & 8,15 & 197,7 & 83,1 \\
\hline
\end{tabular}

The output of peasant farm enterprises for 1 ruble of loans issued was higher by $26.7 \%$ than that of agricultural consumer cooperatives. In 2009, this indicator exceeded the values of the latter by four times. When compared with the subsidies received in 2019, agricultural consumer cooperatives produced $67,4 \%$ more products. In 2009 , there was a reverse 
situation. Peasant farm enterprises received 17.4 times more products per 1 ruble of subsidies.

There was a significant increase in all indicators when comparing the efficiency of loans and grants allocated to agricultural consumer cooperatives in 2019 and 2009. As to peasant farm enterprises, there was a rise only in the production of products per 1 ha of farmland. In general, the mechanism for evaluating the efficiency of state support needs to be developed.

Performance evaluation for 2019 is based on marginal revenue (the calculation is based on the consolidated financial statements for 2019).

Table 3. Efficiency of production and financial activities of business forms depending on marginal revenue in 2019

\begin{tabular}{|c|c|}
\hline Indicators & $\begin{array}{c}\text { Microbusinesses (agricultural businesses } \\
\text { of the Republic of Bashkortostan) } \\
\text { up to 120million ruble }\end{array}$ \\
\hline $\begin{array}{c}\text { Number of producers, units } \\
\text { Total marginal revenue, } \\
\text { million dollars }\end{array}$ & 3233 \\
\hline $\begin{array}{c}\text { The volume of state support provided, } \\
\text { million dollars }\end{array}$ & 9767 \\
\hline $\begin{array}{c}\text { Tax deductions and payments to extrabudgetary funds, } \\
\text { million dollars. }\end{array}$ & 1180 \\
\hline Cost-effectiveness with state support, \% & 281 \\
\hline Cost-effectiveness without state support, \% & 7,6 \\
\hline $\begin{array}{c}\text { Budget efficiency (paid taxes and deductions to extra- } \\
\text { budgetary funds based on received subsidies), million } \\
\text { dollars }\end{array}$ & 0,24 \\
\hline $\begin{array}{c}\text { Number of employees, people } \\
\text { dollars/person }\end{array}$ & 14887 \\
\hline Marginal income per 1 employee, thousand \\
\hline
\end{tabular}

The results of production efficiency calculations indicated that the current set of measures for microbusiness development provides profitable production $-25.6 \%$, when state support is excluded from the calculation, the profitability decreases sharply (-18 percentage points).

\section{Conclusion}

This study provides evidence that small agricultural businesses in Russia get direct support from the state.

Having analyzed the existing budget efficiency methods, some scientists claimed that they affect either its particular directions or determine the impact of subsidies on higher agricultural production profitability [29]. The authors' generalized indicators make it possible to evaluate the entire state support measures for agriculture in an aggregated form. Still, many of them are difficult to perceive since they are based on mathematical apparatus. Therefore, it is considered appropriate to use an indicative assessment of the state program's target indicators. The given research directly relies on indicators used by experts-analysts in the field of agriculture. It makes analysis accessible and understandable for a manager and expert of any business entity $[8,9]$.

It is necessary to evaluate the effectiveness of state support for small businesses in a particular region of Russia both by the criteria set out in the state program and by the ratio 
of payments made to the budget and extra-budgetary funds to the amount of grants and subsidies received from the consolidated budget of the region [11].

Presently different agricultural producers get the support that does not directly affect the results and increase production (refund of insurance burden, compensation for losses in emergencies) while applying incentive measures for small businesses (soft lending, recharge of production costs) is effective.

\section{References}

1. A.A. Askarov, E.V. Stovba, Bulletin of Belgorod University of cooperation, Economics, and Law, 4(44), 178 (2012).

2. A.A. Askarova, I.N. Girfanova, G.R. Nigmatullina, IOP Conference Series: Earth and Environmental Science, 421(2), 022026 (2020).

3. M. Belyaev, S. Sokolova, S. Karpushova, SHS Web of Conferences, 35, 01025 (2017)

4. D. Charlton, J.E. Taylor, S. Vougioukas, Z. Rutledge, Choices, 34(2), 1 (2019).

5. Government of the Russian Federation Federal law No. 209-FZ of 24 July 2007 "On the development of small and medium businesses in the Russian Federation" (latest version), 2007. http://docs.cntd.ru/document/902053196

6. Government of the Russian Federation. Resolution of the Government of the Russian Federation No. 717 of 14 July 2012 "On the State program for the development of agriculture and regulation of markets for agricultural products, raw materials and food" (ed. 25.06.2020), 2012. https://mcx.gov.ru/activity/state-support/programs/program2013-2020/

7. Government of the Russian Federation. The decree of the Russian Federation Government No. 999 of 30 September 2014 "On formation, granting and distribution of subsidies from the Federal budget to budgets of subjects of the Russian Federation" (together with "Rules of formation, granting and distribution of subsidies from the Federal budget to budgets of subjects of the Russian Federation"(ed. 27.07.2020), 2014. https://rg.ru/2014/10/07/pravila-site-dok.html

8. T.V. Govorunova, I.A. Rodionova, V.I. Noroviatkin, K.S. Grischenko, Agricultural scientific journal, 2, 70 (2017).

9. M.V. Panasyuk, L.N. Safiullin, I.R. Gafurov, A.R. Safin, Mediterranean J. of Social Sciences, 5(28), 56 (2014).

10. N. Potori, M. Kovács, V. Vásáry, Studies in Agricultural Economics, 115(1316-2016102801), 118 (2013).

11. M. Svanidze, L. Götz, Global Food Security, 21, 60 (2019).

12. V.I. Trukhachev, I.Y. Sklyarov, Y.M. Sklyarova, S.M. Gorlov, A.V. Volkogonova, Montenegrin J. of Economics, 14(3), 95 (2018).

13. F. Wu, B. Qushim, M. Calle, Z. Guan, Government support in Mexican agriculture. Choices, 33(3), 1 (2018) 